\title{
Macrobenthic Community Structure Response to Coastal Hypoxia off Southeastern Arabian Sea
}

\author{
Baban SI*, Periasamy R and Kalyan D \\ CSIR-National Institute of Oceanography, Dona Paula, Goa, India
}

\begin{abstract}
The analysis of changes in macrobenthic community using multivariate statistical techniques has been applied to find the structure by the environmental condition. The aim of the study was to evaluate macrofaunal community patterns between natural occurrence of coastal hypoxia condition (30 to $100 \mathrm{~m}$ depth) and normoxic bottom waters over the Southeastern Arabian Sea (SEAS). The macrofaunal communities patterns were analyzed by using various statistical methods (e.g. rank correlation, hierarchical clustering, nMDS, BIO-ENV). A clear seasonal difference was found in macrofaunal abundance, biomass, taxonomic composition, diversity and their relation to environmental conditions. Multivariate analysis of Non Multidimensional Scaling (nMDS) showed two major groups macrofaunal communities and ANOSIM results showed a significant difference between macrofaunal community structure in between nornaxia and hypoxia conditions ( $R=0.913)$. Spearman rank correlation (using BIO-ENV procedure included in PRIMER, V.6) showed the highest correlation of dissolved oxygen $(R=0.678)$ with community structure. The SIMPER analysis illustrated community pattern changed seasonally with Paraprionospia cordifolia (20.03\%) dominated during hypoxia whereas Tharyx sp. $(22.63 \%)$ dominated in nornaxia conditions. The macrofaunal community patterns revealed contrasting pattern with two seasons, perhaps due to the dissolved oxygen (DO).
\end{abstract}

Keywords: Hypoxia; Normoxia; Macrobenthos; Community structure; Dissolved oxygen

\section{Introduction}

Changes in the structure and composition of macrobenthic communities driven by environmental condition may have marked effects on biogeochemical cycles and benthic ecosystem processes and functions. They are sedentary and trophically diverse [1] and their communities mix the effects of water and sediment changes over time. In addition, macrobenthic fauna play an important ecological role within food webs. They are a direct and indirect food source for many animals, including large crustaceans, fishes, marine birds and marine mammals [2]. Macrobenthic communities can also alter physical and chemical conditions at the sediment-water interface, promote decomposition of sediment organic matter $(\mathrm{OM})$, and are important mediators in nutrient recycling from the sediments to the water column through bioturbation and suspension feeding activities $[3,4]$. Therefore, changes in macrobenthic community composition, abundances and diversity can affect the functioning of the entire ecosystem [5].

Macrobenthic communities are composed of sedentary organisms capable of integrating long-term environmental conditions at a particular site [6]. Large areas of high productivity induced by natural upwelling and limited mixing led to decrease in the Dissolved Oxygen (DO) concentration at coastal regions $[7,8]$. Studies defined that DO concentration at normoxia is $>2.8 \mathrm{mgL}^{-1}$, mild hypoxia $2.1-2.8 \mathrm{mgL}^{-1}$, and hypoxia is $\leq 2 \mathrm{mgL}^{-1}$. The lower concentration of DO has a major impact on structure and functioning of biogeochemical processes such as the carbon, nitrogen cycles $[9,10]$ and benthic ecology $[11,12]$. During the southwest monsoon the southward movement of the West Indian coastal current influences the upwelling and it causes the hypoxia condition in the Arabian Sea [13]. During southwest monsoon the coastal upwelling occurs along west coast of India between $7^{\circ} \mathrm{N}$ and $14^{\circ} \mathrm{N}$ [14-16].

Hypoxia is the most intense marine environments based on harshness conditions in sediment and water flux; also it alters the marine benthic communities. The effects of hypoxia condition on biological community are frequent and related to different levels of dwelling and tolerance. Such responses may change to the feeding habit and also reduced the predator population $[17,18]$. Hypoxia conditions leads to changes in macrofaunal community structure marine benthic ecosystem due to physiological changes such as stratification and mixing [7,19-23]. Hypoxic events will increase the susceptibility of coastal marine ecosystems to further hypoxia through alteration of ecosystem functioning of the sediments and show that this has already occurred in a number of coastal marine ecosystems [22].

The effect of hypoxia conditions on macrobenthic community have been studied by many researchers [24-26]. The macrobenthic abundance has been reduced in the Arabian Sea due to deceased levels of DO during winter. Many of the inshore regions exhibit poor water quality due to extensive domestic and industrial waste disposal; very low dissolved oxygen occurs during post monsoon in fall, which is mainly due to anoxia developing along the open coastal [23]. There is no study so far in the coastal SEAS explaining the effect of very low dissolved oxygen on macrofauna. However, it is known that macrofaunal communities may response in a different way to the normoxia and hypoxia condition and thus DO play a vital role in benthic ecosystem functioning. The aim of the present study is to assess the macrofaunal structural changes between normoxia and hypoxia conditions and to predict spatio-temporal variation of benthic biodiversity.

*Corresponding author: Baban S Ingole, CSIR-National Institute of Oceanography, Dona Paula, Goa-403004, India, Tel: +011-26043258; E-mail: baban@nio.org

Received December 12, 2016; Accepted December 26, 2016; Published December 30, 2016

Citation: Baban SI, Periasamy R, Kalyan D (2016) Macrobenthic Community Structure Response to Coastal Hypoxia off Southeastern Arabian Sea. J Coast Zone Manag 19: 436. doi:10.4172/2473-3350.1000436

Copyright: ( 2016 Baban SI, et al. This is an open-access article distributed under the terms of the Creative Commons Attribution License, which permits unrestricted use, distribution, and reproduction in any medium, provided the original author and source are credited. 


\section{Materials and Methods}

\section{Study area}

The study was carried out at two fixed Transects, off Cochin $\left(9^{\circ} 56^{\prime} \mathrm{N}\right.$ and $\left.76^{\circ} 12^{\prime} \mathrm{E}\right)$ and off Trivandrum $\left(8^{\circ} 28^{\prime} \mathrm{N}\right.$ and $\left.76^{\circ} 54^{\prime} \mathrm{E}\right)$ along the coastal water of SEAS perpendicular to western Ghats which receives bulk of rain fall during tropical South-West monsoon regime (Figure 1). The sampling was carried out with the CORV Sagar Sukti at SIM and on FORV Sagar Sampada during for coastal upwelling during the peak of the South-West monsoon season. In each transect, three stations (bottom depth 30,50 and $100 \mathrm{~m}$ ) were chosen for studying the various environmental parameters and macrofauna community structure.

\section{Physio-chemical characteristics}

In order to measure the bottom dissolved oxygen concentration, a modified Niskin type water sampler which is capable of collecting bottom water above $20 \mathrm{~cm}$ from the surface sediment was used. Dissolved oxygen was analyzed by Winkler's method [27]. Water depth, salinity and temperature of water column were measured using a CTD meter (SBE-19, Sea-Bird Electronics).

\section{Macrofaunal sampling and analysis}

The sediment samples were collected using Smith-McIntyre grab of 0.2 sq.m surface areas, triplicate grab samples were collected, and sieved through a $0.5 \mathrm{~mm}$ mesh screen, and the retained organisms were preserved in $10 \%$ buffered formalin with Rose Bengal solution in plastic bags. Once the samples brought to laboratory, macrofauna were carefully washed again and sorted into major taxonomic groups (phylum, order or class) and preserved in 5\% buffered formalin. The faunal counts from individual grabs were averaged and converted to individual per sq. meter. The faunal counts from the water overlying the grabs were divided by the number of sub-cores taken. Biomass $(\mathrm{g} /$ $\mathrm{m}^{2}$ ) was determined by using the wet weight method after blotting. The biomass (shell on) was estimated similarly and converted to g.m ${ }^{-2}$ (wet weight). As polychaeta were dominated taxa, then were identified up to species $[28,29]$ level if possible and their number was counted as individual per square meter under stereo-microscope.

\section{Statistical analysis}

Macrobenthos data were subjected to univariate analyses to study community structure using Margalef's index [30] for species richness (d), Pielou's index [31] for species evenness $\left(J^{\prime}\right)$, and the Shannon-Wiener index [32] for species diversity $\left(H^{\prime}\right.$ by using $\left.\log ^{2}\right)$. For multivariate analysis, a square-root transformation of biological abundance data was carry out and contributed most to the observed differences among

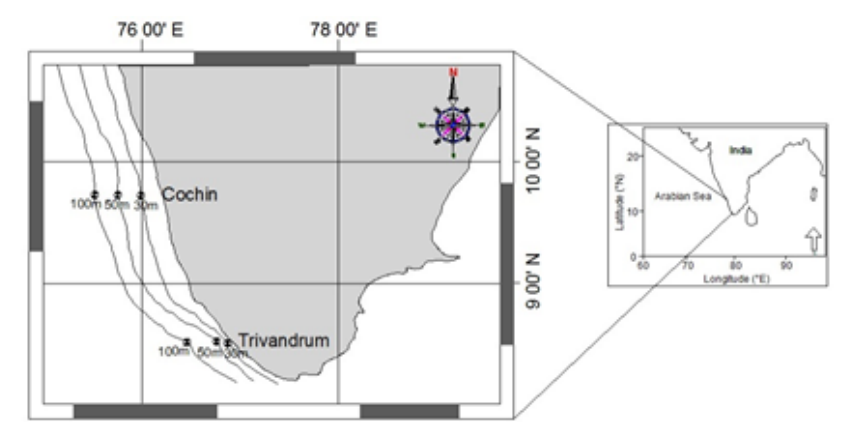

Figure 1: Map showing the study area and sampling locations for macrobenthos in Southeastern Coast of Arabian Sea. groups were found by means of SIMPER (similarity percentage) and cluster analysis and nMDS (Non-metric multidimensional scaling) ordination stand on the Bray-Curtis similarity matrix were attained using the PRIMER 6 package (Plymouth Routines in Multivariate Ecological Research) [33]. Similarity profile (SIMPROF) test was carried out to detect the significant of the clusters. The null hypothesis of no inside group structures of occupied samples was rejected when significance level of $\mathrm{P}<0.05$. ANOVA analysis was carried to find out the significance of spatial and temporal variation on the environmental and biological parameters. Types of feeding were assigned to polychaetes based on the previous reports.

\section{Results}

\section{Environmental characteristics}

Physico-chemical characteristics such as temperature, salinity and DO (DO saturation \%) along SEAS during SM and SIM conditions are shown in Table 1. The results showed that cold and low oxygen condition in the bottom water during SM. Notable feature was observed that the bottom water salinity did not vary along different water depths, whereas temperature showed variation between seasons range from 20.3 to $30.4^{\circ} \mathrm{C}$ in SIM and 19.6 and $23.5^{\circ} \mathrm{C}$ during SM (ANOVA, $\mathrm{P}<0.05$ ). DO deficient of near bottom-water during the SM showed ranged from 0.038 to $0.804 \mathrm{mg} . \mathrm{L}^{-1}$, while oxygen saturated conditions during SIM DO ranged from 4.38 to 5.5 mg.L $L^{-1}$ (Figure 2 ) and significantly differed between both season (ANOVA, $\mathrm{P}<0.05$ ).

\section{Macrofaunal composition}

The highest number of taxa (68) was identified in the SIM, and Polychaeta was dominated group, contributing $86.21 \%$ to total fauna abundance. Macrofaunal abundance decreased from depths 30$100 \mathrm{~m}$ in Cochin (5556 - 3520 individuals $\mathrm{m}^{-2}$ ), then increased from shallow depth to deep on Trivandrum (1529-2493 individuals $\mathrm{m}^{-2}$ ) and average abundance 3412 individuals $\mathrm{m}^{-2}$ were in the SIM (Table 2). Moreover, 25 polychaete families were found in the SIM, in which Cirratulidae family were showed highest contribution (39.81\%) followed by Spionidae (14.2\%) and Capitellidae (5.37\%). The SIMPER analyses showed that benthic community was dominated by Tharyx sp. (22.63\%) and Mediomastus sp. (10.48\%) at SIM (Table 3). On the other hand P. cordifolia (20.03\%) and Cirriformia sp. (12.19\%) showed major dominance in benthic community during SM. The overall mean abundance was 3383 individuals' $\mathrm{m}^{-2}$ with minimal value Cochin 100 $\mathrm{m}$ depth (650 individuals $\mathrm{m}^{-2}$ and 8 taxa) and polychaeta groups were contributing $86.8 \%$ on benthic faunal abundance. Among these families, highest contributions of Spionidae and Crustacean were dominated (56.45\% and $11.58 \%$ respectively) followed by Chaetopteridae (5\%), Orbiniidae (4.63\%), Sabellidae (4.17\%) and Glyceridae (3.41\%) (Table 4). The Amphipoda was most abundance group among the crustaceans, contributing $8.05 \%$ to total macrofaunal diversity. However, the low abundance of Echinodermada and Fish larva were observed at the low oxygen conditions. The average biomass showed that the higher biomass value (16.5 g.m $\mathrm{m}^{-2}$ ) found at low oxygen environmental conditions (Figure 3).

\section{Diversity indices}

Margalef's index (d) showed that species richness (d) was varied from 2.4 to 7.4 during SIM, while hypoxia zone (SM) was recorded lower $\mathrm{d}$ value from 1.7 to 4.98 (Figure 4 ). The species evenness (J) varied from 0.87 to 0.95 in high oxygen conditions, whereas in low oxygen conditions species evenness range of 0.93 to 0.98 . However, highest value of Shannon diversity index $\left(\mathrm{H}^{\prime}\right)$ varied from 3.72 to 5.19 
Citation: Baban SI, Periasamy R, Kalyan D (2016) Macrobenthic Community Structure Response to Coastal Hypoxia off Southeastern Arabian Sea. J Coast Zone Manag 19: 436. doi:10.4172/2473-3350.1000436

Page 3 of 10

\begin{tabular}{|c|c|c|c|c|c|c|c|c|c|}
\hline \multirow[t]{2}{*}{ Transect } & \multirow[t]{2}{*}{ Depth (m) } & \multicolumn{2}{|c|}{ Temp $\left({ }^{\circ} \mathrm{C}\right)$} & \multicolumn{2}{|c|}{ Salinity PSU } & \multicolumn{2}{|c|}{ Dissolved oxygen (ml. $\left.\mathrm{L}^{-1}\right)$} & \multicolumn{2}{|c|}{$\begin{array}{l}\text { Dissolved oxygen } \\
\text { (saturation \%) }\end{array}$} \\
\hline & & SIM & SM & SIM & SM & SIM & SM & SIM & SM \\
\hline \multirow{3}{*}{ Cochin } & 30 & $30.46 \pm 0.5$ & $22.77 \pm 0.8$ & $35.71 \pm 0.4$ & $35.05 \pm 0.3$ & $4.70 \pm 0.7$ & $0.04 \pm 0.8$ & 91 & 1 \\
\hline & 50 & $28.47 \pm 0.7$ & $21.72 \pm 0.5$ & $35.48 \pm 0.3$ & $35.03 \pm 0.9$ & $4.45 \pm 0.8$ & $0.14 \pm 0.7$ & 83 & 2 \\
\hline & 100 & $20.30 \pm 0.3$ & $19.59 \pm 0.3$ & $35.37 \pm 0.4$ & $34.95 \pm 0.5$ & $5.13 \pm 0.3$ & $0.16 \pm 0.9$ & 82 & 3 \\
\hline \multirow{3}{*}{ Trivandrum } & 30 & $29.74 \pm 0.8$ & $23.46 \pm 0.9$ & $34.76 \pm 0.9$ & $35.01 \pm 0.4$ & $4.38 \pm 0.3$ & $0.80 \pm 0.7$ & 84 & 14 \\
\hline & 50 & $27.60 \pm 0.3$ & $22.61 \pm 1.2$ & $35.27 \pm 1.1$ & $35.01 \pm 0.8$ & $5.50 \pm 0.4$ & $0.36 \pm 0.4$ & 101 & 6 \\
\hline & 100 & $24.63 \pm 0.9$ & $20.71 \pm 1.5$ & $35.34 \pm 0.7$ & $34.93 \pm 1.3$ & $4.75 \pm 0.9$ & $0.21 \pm 0.4$ & 82 & 3 \\
\hline
\end{tabular}

Note: Mean $\pm \operatorname{SD}(n=3)$

Table 1: Physico-chemical characteristic of habitats study (mean \pm SD) on the southeastern Arabian Sea.

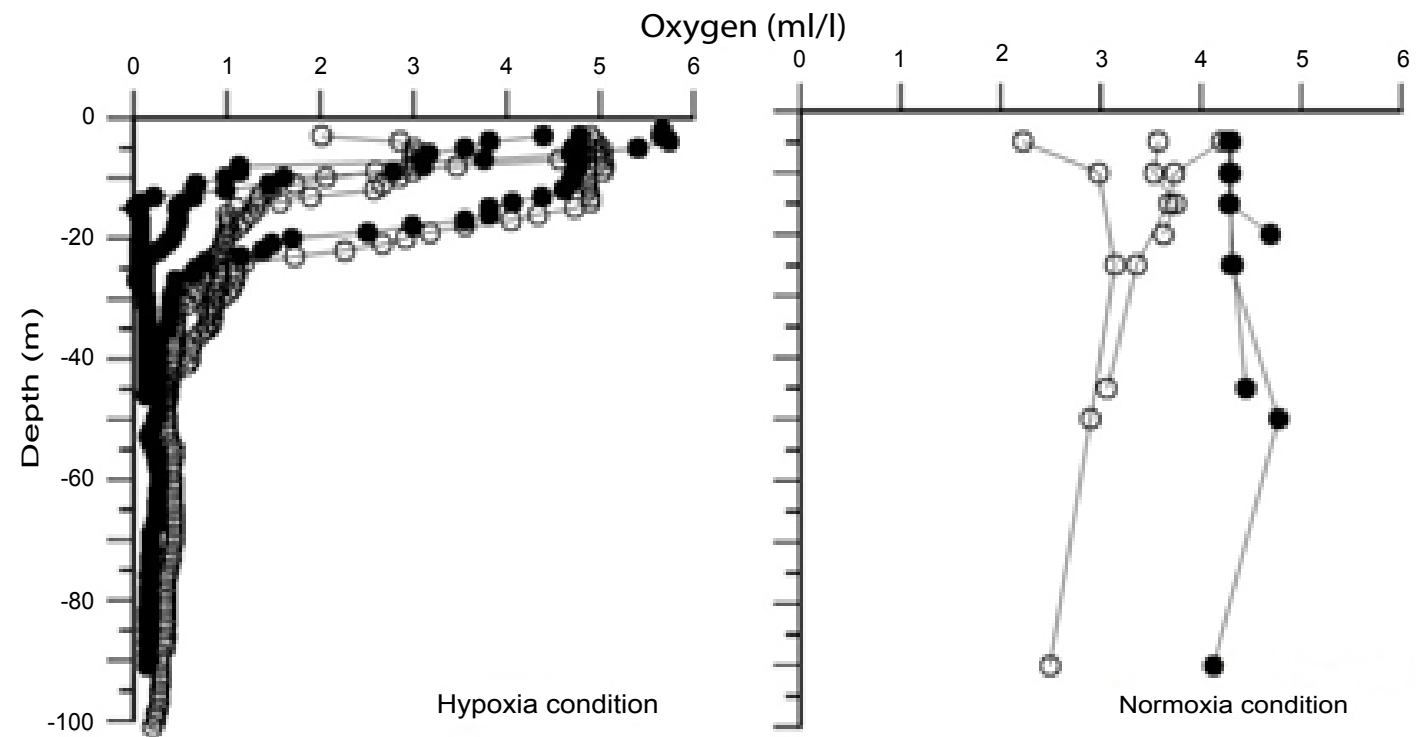

Cochin Trivandrum

Figure 2: Season-wise distribution of $\mathrm{DO}\left(\mathrm{mL}^{-1}\right)$ during SIM and SM conditions.

\begin{tabular}{|c|c|c|c|c|c|c|c|c|c|c|c|c|}
\hline \multirow{3}{*}{$\begin{array}{c}\text { Zones } \\
\text { Transects } \\
\text { Water Depth }(\mathrm{m})\end{array}$} & \multicolumn{6}{|c|}{ Spring Inter Monsoon } & \multicolumn{6}{|c|}{ Summer Monsoon } \\
\hline & \multicolumn{3}{|c|}{ Cochin } & \multicolumn{3}{|c|}{ Trivandrum } & \multicolumn{3}{|c|}{ Trivandrum } & \multicolumn{3}{|c|}{ Cochin } \\
\hline & 30 & 50 & 100 & 30 & 50 & 100 & 30 & 50 & 100 & 30 & 50 & 100 \\
\hline Total abundance(Ind. $\left.\mathrm{m}^{-2}\right)$ & 1499 & 2443 & 2261 & 4814 & 5506 & 3954 & 1675 & 4475 & 650 & 7450 & 5025 & 1025 \\
\hline Total number of species & 38 & 39 & 27 & 21 & 14 & 22 & 15 & 29 & 15 & 25 & 27 & 22 \\
\hline Total Biomass (wet wt. g.m²) & 12.66 & 4.82 & 1.34 & 10.7 & 166.2 & 1.30 & 6.06 & 20.02 & 7.45 & 42.03 & 14.03 & 9.39 \\
\hline $\begin{array}{l}\text { Most dominant species* (comprising } \\
>10 \% \text { ) of the density }\end{array}$ & 1802 & 2289 & 1311 & 311 & 1111 & 955 & 1550 & 3550 & 325 & 275 & 1375 & 200 \\
\hline Dominant feeding types & SDF & SDF & SDF & SDF & SDF & SDF & SDF & SDF & SDF & SDF & SDF & SDF \\
\hline$d$ & 4.46 & 4.45 & 3.25 & 2.75 & 1.67 & 2.75 & 1.89 & 3.34 & 1.99 & 2.67 & 3.08 & 2.94 \\
\hline $\mathrm{J}^{\prime}$ & 0.55 & 0.68 & 0.69 & 0.80 & 0.74 & 0.70 & 0.90 & 0.68 & 0.92 & 0.79 & 0.73 & 0.85 \\
\hline $\mathrm{H}^{\prime}\left(\log ^{2}\right)$ & 2.89 & 3.61 & 3.29 & 3.55 & 2.81 & 3.12 & 3.54 & 3.28 & 3.61 & 3.65 & 3.46 & 3.78 \\
\hline
\end{tabular}

Note: (Dominant species*1: Paraprinospia cordifolia, 2: Prinospia cirrifera, 3: Tharyx sp.), SDF: Surface deposit feeder

Table 2: Comparison of community parameters studied along the two transects during two different seasons at SIM and SM.

in SIM, whereas in SM value ranged from 2.93 to 4.52.

\section{Linking macrofauna community structure to environmental variables -bio-env}

The BIO-ENV procedure was explained on a species assemblage similarity matrix attuned for two sites and the resemblance matrices created using one various transformations of primary environmental 106-by-3 matrix (Temperature, salinity and DO are log-transformed prior to the normal transformation). The Spearman correlation coefficient (r) was selected as a rank correlation measure. For the normal transformed environmental matrix, DO revealed the best association with the abundance, $(\mathrm{r}=0.709)$. It was followed by J ( $\mathrm{r}=0.590)$ (Figure 5). Those variables were liable for most of the similarity between the biotic and abiotic matrices (Table 5). The highest correlation $(r=0.597)$ 
Citation: Baban SI, Periasamy R, Kalyan D (2016) Macrobenthic Community Structure Response to Coastal Hypoxia off Southeastern Arabian Sea. J Coast Zone Manag 19: 436. doi:10.4172/2473-3350.1000436

Page 4 of 10

\begin{tabular}{|c|c|c|c|}
\hline Hypoxic intolerant species (SIM) & Composition (\%) & Hypoxic tolerant species( SM) \\
\hline Tharyx sp. & 22.63 & Paraprionospio cordifolia \\
\hline Mediomastus sp. & 10.48 & Prionospio pygmaea \\
\hline Lumbrineris sp. & 6.34 & Cirriformia sp. \\
\hline Prinospia cirrifera & 5.45 & Prinospia cirrifera \\
\hline Paraprinospia cordifolia & 3.74 & Glycera alba \\
\hline Prionospio aucklandica & 3.3 & Prionospio steenstrupi \\
\hline Aricidea sp. & 3.18 & 13.04 \\
\hline Nepthys sp. & 2.73 & Magelona sp. \\
\hline
\end{tabular}

Table 3: Comparison of similarity of macro fauna observed among the dominant species from normoxic and hypoxic condition.

\begin{tabular}{|c|c|c|c|}
\hline Hypoxic intolerant (SIM) & $\%$ & Hypoxic tolerant (SM) & $\%$ \\
\hline Cirrtulidae & 39.81 & Spionidae & 56.45 \\
\hline Spionidae & 14.20 & Crustacea & 11.58 \\
\hline Capitellidae & 5.37 & Chaetopteridae & 5.00 \\
\hline Paraonidae & 4.21 & Orbiniidae & 4.63 \\
\hline Gastropoda & 2.85 & Sabellidae & 4.17 \\
\hline Bivalvia & 2.80 & Glyceridae & 3.41 \\
\hline Nereididae & 2.56 & Cirrtulidae & 3.17 \\
\hline
\end{tabular}

Table 4: Dominant macrobenthic taxa tolerating from SIM and SM seasons.

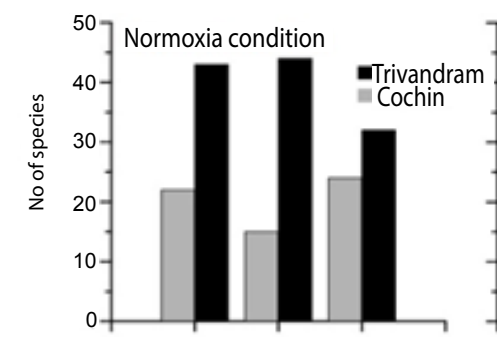

Hypoxia condition
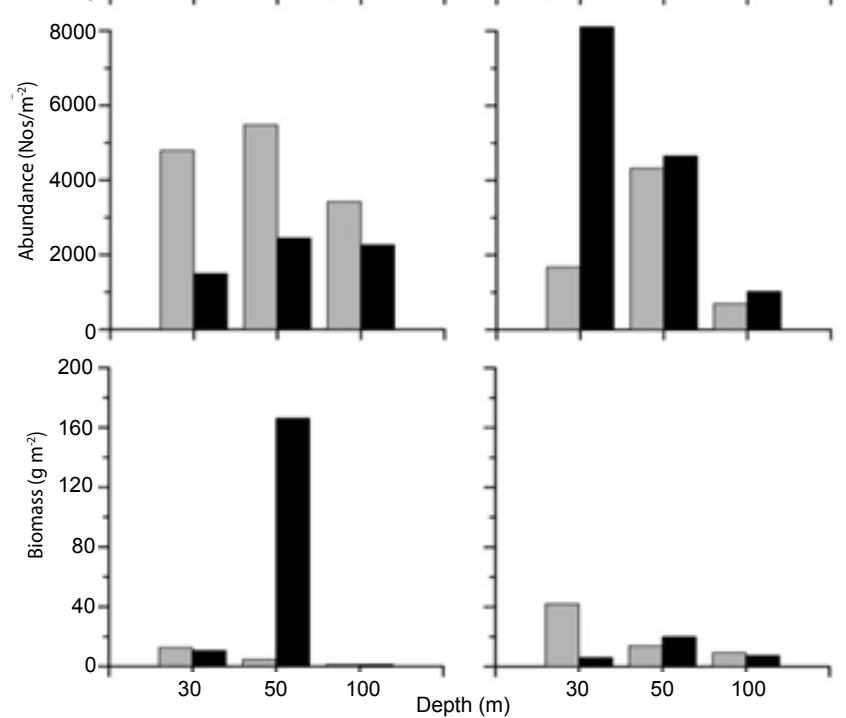

Figure 3: Season-wise distributions of macrofaunal species, abundance and biomass at the southeastern Arabian Sea.

is found for a combination of factors: Abundance; Temperature; DO.

Multivariate (MDS) analysis of macrofaunal community structure

The MDS plot based on the abundance of macrofauna communities shows two different groups at dissimilarity (84.59\%) in this study area (Figure 6). The SIM group was differentiated by Tharyx sp. and

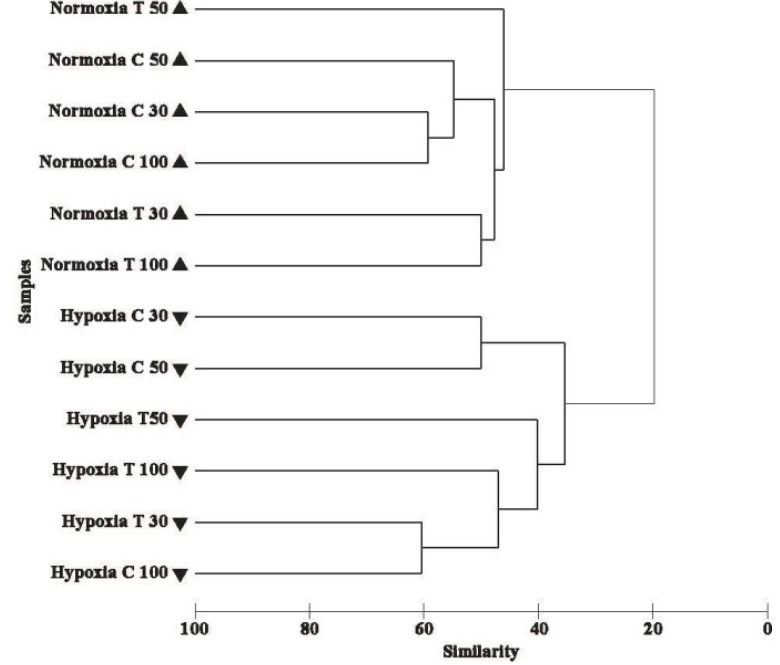

Figure 4: Dendrograms and MDS plots based on the macrobenthos abundance data.

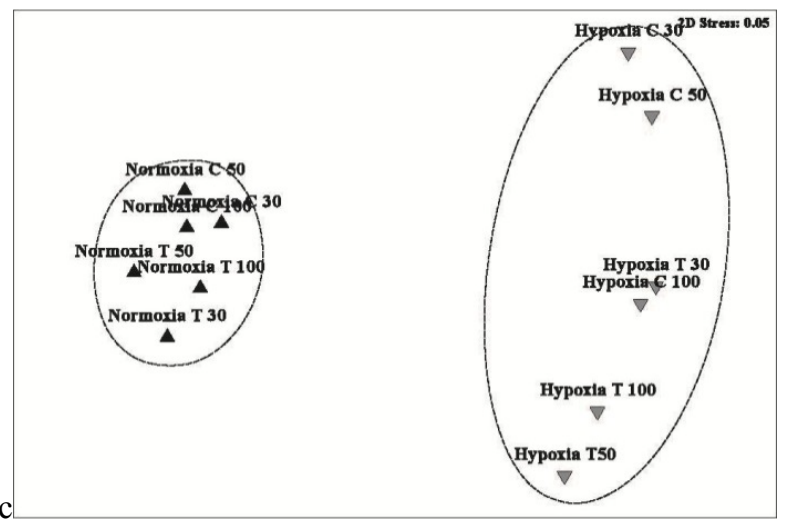

Figure 5: Bray-Curtis similarity for seasonal conditions (normoxia and hypoxia).

Mediomastus sp. whereas SM group were dominated by $P$. cordifolia and Cirriformia sp. (Table 3). An ANOSIM ( $\mathrm{R}=0.913)$ test shows the significant differences between season (SIM and SM) and BrayCurtis analysis explains two distinct clusters at 20\% similarity (Figure 7). Most of the surface and subsurface deposit feeder in cluster was mainly from the oxygen saturated conditions and they were also showed low abundance in the hypoxia conditions. The surface deposit feeder of polychaete such as Tharyx sp. and subsurface deposit feeder of Mediomastus sp. were abundant along with carnivore species 


\begin{tabular}{|c|c|c|}
\hline $\begin{array}{c}\text { Number of } \\
\text { variables }\end{array}$ & Best variable combinations & Correlation $\left(\boldsymbol{\rho}_{\mathbf{w}}\right)$ \\
\hline 1 & Dissolved Oxygen & 0.633 \\
\hline 2 & Abundance-Dissolved Oxygen & 0.709 \\
\hline & J'-Dissolved Oxygen & 0.590 \\
\hline & d-Dissolved Oxygen & 0.588 \\
\hline & No of species-Dissolved Oxygen & 0.570 \\
\hline & H'(log2)-Dissolved Oxygen & 0.550 \\
\hline & Abundance-J'-Dissolved Oxygen & 0.599 \\
\hline & Abundance-Temperature-Dissolved & 0.597 \\
\hline & Oxygen & 0.588 \\
\hline & Abundance-salinity-Dissolved Oxygen & 0.582 \\
\hline & Abundance- H'(log2)-Dissolved Oxygen & \\
\hline
\end{tabular}

Table 5: BIO-ENV procedure results showed that highest Spearman rank correlation coefficients $(\rho)$ evaluated between square root of transformed biotic similarity matrix and abiotic matrix $\left(\rho_{\text {normal }}\right)$

Lumbrineris sp. Another cluster was formed due to the abundance of P. cordifolia, Prionospio pygmaea and Cirriformia sp. included carnivore polychaeta such as Glycera alba.

\section{Distribution of polychaeta feeding type}

The surface deposit feeder was dominant feeding type (dwelling polychaeta) $78.5 \%$ with carnivores (17\%) in the hypoxia zone (SM). The both surface and subsurface feeder existed $74.3 \%$ with carnivore (12\%) in the normoxia condition. P. cordifolia was highest dominated as well as it also feeder tolerated at low oxygen condition; consequently the suspension of deposit feeder or filler feeders (4.6\%) were uncommon in low oxygen zone (SM) (Table 6). There is also a common propensity for suspended feeders to be replaced by deposit feeders, in contest that second order opportunistic species were dominated during SM. The low oxygen condition showed highest representation of carnivores (17\%) on the surface of bottom than carnivores (12\%) at SIM conditions.

\section{Discussion}

The seasonal upwelling may have influence on the biological productive region in and around the Arabian Sea. The nutrient rich in upwelled water causes oxygen shortage in the subsurface water along the SEAS during SM. The observed high DO values on the normoxia zone and low $\mathrm{DO}$ values in the hypoxic zone were in agreement with earlier studies of the west coast of India (Muni Krishna 2008). The lowest DO value ranged from 0.04-0.8 ml. $\mathrm{L}^{-1} \mathrm{SM}$, whereas high DO values (4.38-5.5 ml. $\left.\mathrm{L}^{-1}\right)$ observed along the normoxia conditions SIM and high tolerance in low oxygen levels has moderately connected with continuously low temperature and oxygen deficiency apt to promoted with decreasing temperature [34-36]. During the SM (June to September) the wind pattern has favored the upwelling along the west coast of Indian. However, the end of the SM indicates that the process cannot be driven by winds alone, but may be remotely forced to a large extent [10]. Studies implied increased intensity of upwelling processes in Cochin during July and creating the drop in sea level as well as surface temperature.

P. cordifolia and Tharyx sp. are opportunistic species belonging to the families of Spionidae and Capitellidae. Both the species are surface deposit feeder and propagate in high organic enrichment sediments [37]. However, Spionidae and Capitellidae contributed to $68 \%$ of the total polychaete species during SM and rich organic content of sediment can support the tolerant species and reduce sensitive species [37]. Among the Polychaetes, two species namely $P$ cordifolia and Prionospio pygmaea, belonging to the Spionidae family and one species of Cirriformia sp. under the Cirratulidae family were abundant on the low oxygen conditions (SM). These surface deposit feeders were replaced by more carnivorous species including Lumbrineris sp., Ancistrosyllis sp., Syllis sp., Notomastus sp. and Cirratulis sp. [38]. Echinoderms are typically more sensitive to hypoxia with lower oxygen thresholds, than annelids, Sipuncula, Molluscs and Cnidarians. Moreover, as shown by the SIMPER analyses, the Spionidae contributed most of the difference between the hypoxic and normoxic conditions. Our results showed that the highest density of the subsurface feeder Mediomastus sp. and Oligochaeta at the normoxia conditions SIM, further the presence of the suspension feeder Megalomma sp. was restricted to the hypoxia conditions.

Although many omnivores are opportunistic and capable to switch prey depending on food availability, thus it is expected that they will balance their diet as a result of nutritional needs, food quality and availability of alternate foods [39]. On contrary, Tharyx sp. and Mediomastus sp. were found at low density during hypoxia conditions. The $P$. cordifolia was dominant macrobenthic species in this DO $(\leq 2$ $\mathrm{mg} \mathrm{L}^{-1}$ ) depleted areas [12,40,41]. The macrobenthos presented in normoxia condition did not cluster with hypoxia group, because of high abundance of P. cordifolia (Figure 8). This species is well-known to tolerated hypoxia conditions $[42,43]$. In addition, study reported that the dominance of P.cordifolia within OMZ off concepection. The rich organic matter in study area was strongly influence on evenness and dominance of macrofauna community. Therefore, it is often complicated to eminent effects of oxygen depletion from those of decreased $\mathrm{pH}$ on taxonomic composition [11].

The low density of macrofauna was observed at Cochin (30 and 100 $\mathrm{m}$ ) during SM, which falls within the site of seasonal sulphate reduction [10]. Typically, the first disappear of crustaceans and echinoderms, with annelids and selected molluscs exhibiting greatest tolerance to hypoxia $[19,44]$. The important taxa of Spionidae and Cossuridae were found in low oxygen level [26]. However, coastal systems are become saturated through organic matter which leads to develop hypoxia condition and reduction in the biomass [45]. The present studies shows that macrofaunal species were interrelated to surroundings conditions and various environmental factors which are playing major role for the changes on macrofauna structural. The surface deposit feeders and low-oxygen tolerant species are dominated over the suspension feeders. However, the low biodiversity were observed mostly sensitive to the hypoxia conditions. According to studies classification of polychaete feeding types during SIM were dominated by surface deposit-feeding with subsurface deposit-feeding fauna playing a major role in the normoxia conditions.

The macrofauna community structure showed the evidence of low biomass supported by lowest oxygen levels during SM. Rowe reported the reduced biomass within low oxygen condition was stress induced small but found that this low biomass involves high macrofaunal densities, indicating small body size. Mobile vertebrate and invertebrate taxa were observed to avoid hypoxic condition and less mobile invertebrate taxa try to escape low-oxygen conditions or even die and if they cannot escape [7]. Further, Spionidae contributed (52.8\%) of the total polychaete family and responses to the hypoxia conditions depend on the duration. The low oxygen conditions to support metazoans, small size of organisms, soft-bodied invertebrates (naturally annelids) and often time of the generation short and intricate branchial structures $[7,46]$. In addition, the polychaetes have high gill surface area enhances respiratory surface and morphological adaptation. Moreover, the 
Citation: Baban SI, Periasamy R, Kalyan D (2016) Macrobenthic Community Structure Response to Coastal Hypoxia off Southeastern Arabian Sea. J Coast Zone Manag 19: 436. doi:10.4172/2473-3350.1000436

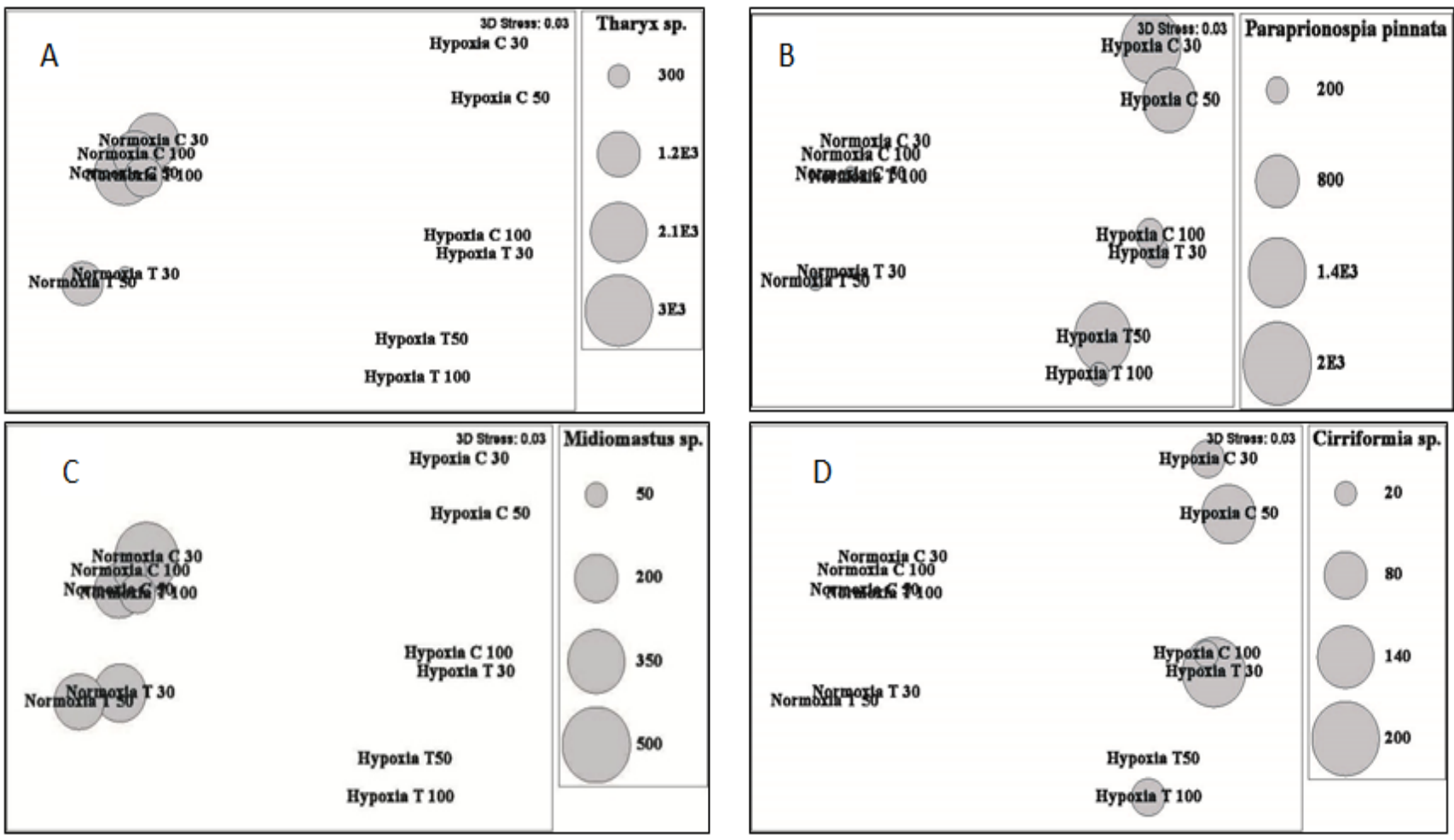

Figure 6: Seasonal distribution of species and abundance pattern.
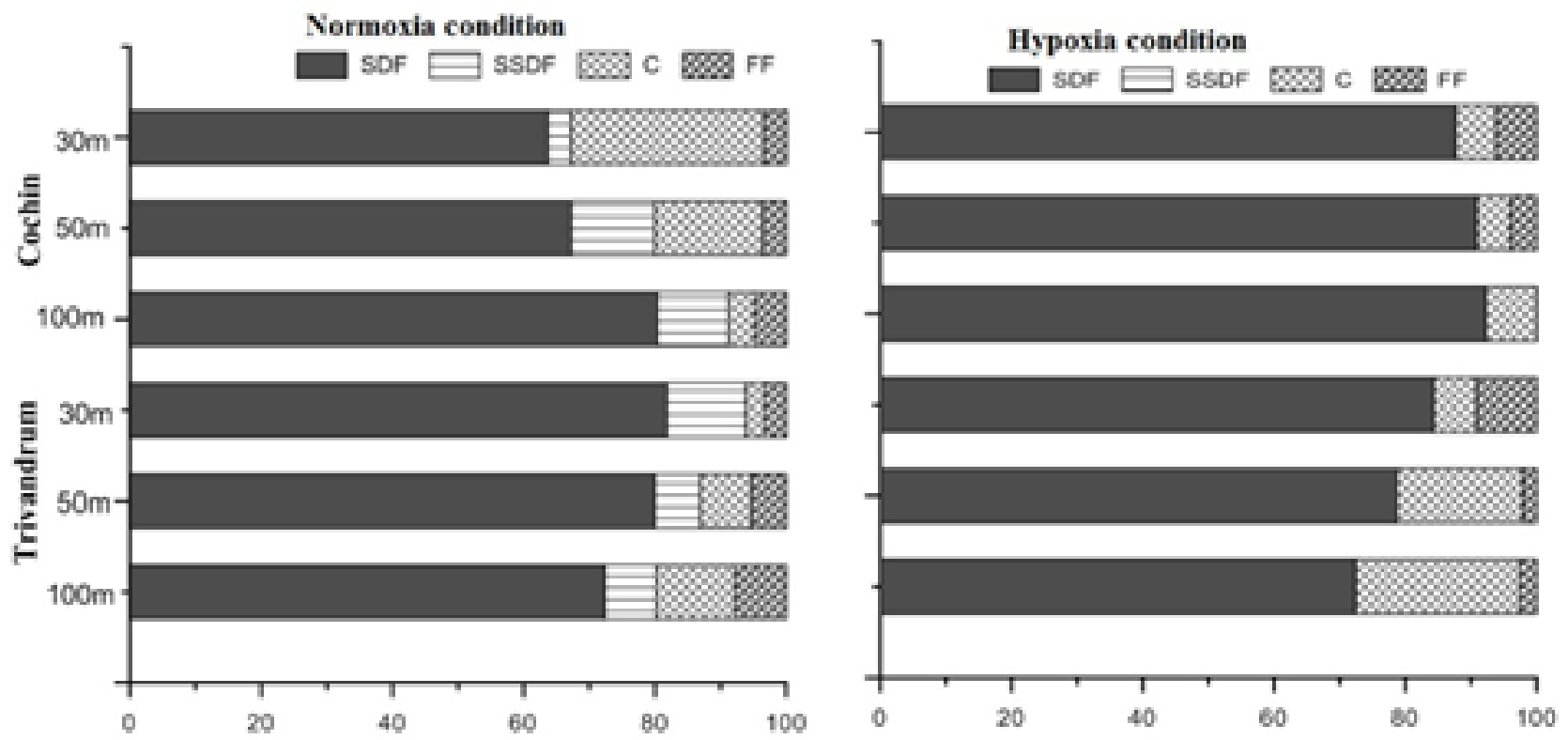

Feeding type composition (\%)

Figure 7: Seasonal distributions of feeding types of macrofauna occurred in southwest coast of Arabian Sea (SDF: surface deposit feeder, SSDF: subsurface deposit-feeder, C: Carnivores and FF: suspension feeder or filter feeder). 
Citation: Baban SI, Periasamy R, Kalyan D (2016) Macrobenthic Community Structure Response to Coastal Hypoxia off Southeastern Arabian Sea. J Coast Zone Manag 19: 436. doi:10.4172/2473-3350.1000436

Page 7 of 10

\begin{tabular}{|c|c|c|c|c|c|c|c|c|c|c|c|c|c|c|}
\hline \multirow{4}{*}{ Group } & \multirow{4}{*}{ Family } & \multirow{4}{*}{ Species name } & \multicolumn{6}{|c|}{ Normoxia zone (SIM) } & \multicolumn{6}{|c|}{ Hypoxia zone (SM) } \\
\hline & & & \multicolumn{3}{|c|}{ Cochin } & \multicolumn{3}{|c|}{ Trivandrum } & \multicolumn{3}{|c|}{ Trivandrum } & \multicolumn{3}{|c|}{ Cochin } \\
\hline & & & \multicolumn{12}{|c|}{ Water depth $(\mathrm{m})$} \\
\hline & & & 30 & 50 & 100 & 30 & 50 & 100 & 30 & 50 & 100 & 30 & 50 & 100 \\
\hline \multicolumn{15}{|l|}{ Polychaeta } \\
\hline & Pilargidae & & & & & & & & & & & & & \\
\hline & & Synelmis sp. & 5 & 0 & 0 & 0 & 0 & 22 & 0 & 0 & 0 & 0 & 0 & 0 \\
\hline & & Ancystrocyllis sp. & 47 & 22 & 0 & 15 & 89 & 0 & 25 & 50 & 0 & 0 & 0 & 25 \\
\hline & Ampharetidae & & & & & & & & & & & & & \\
\hline & & Amphicteis sp. & 0 & 22 & 0 & 0 & 0 & 0 & 0 & 0 & 0 & 0 & 0 & 0 \\
\hline & Opheliidae & & & & & & & & & & & & & \\
\hline & & Armandia sp. & 0 & 22 & 0 & 0 & 0 & 0 & 0 & 0 & 0 & 0 & 0 & 0 \\
\hline & Maldanidae & & & & & & & & & & & & & \\
\hline & & Axiothella sp. & 0 & 67 & 0 & 0 & 0 & 0 & 0 & 0 & 0 & 0 & 0 & 0 \\
\hline & Capitellidae & & & & & & & & & & & & & \\
\hline & & Midiomastus sp. & 425 & 156 & 0 & 89 & 267 & 133 & 0 & 0 & 0 & 0 & 0 & 0 \\
\hline & Chaetopteridae & & & & & & & & & & & & & \\
\hline & & Chaetopterus sp. & 2 & 22 & 0 & 0 & 44 & 0 & 0 & 1025 & 0 & 0 & 0 & 0 \\
\hline & Cirrtulidae & & & & & & & & & & & & & \\
\hline & & Cirratulidae sp. & 0 & 0 & 0 & 44 & 0 & 22 & 0 & 0 & 0 & 0 & 0 & 0 \\
\hline & & Cirriformia sp. & 0 & 0 & 0 & 0 & 0 & 0 & 175 & 0 & 50 & 50 & 125 & 25 \\
\hline & & Cirratulus sp.1 & 0 & 0 & 0 & 0 & 44 & 0 & 0 & 0 & 0 & 0 & 0 & 0 \\
\hline & & Cirratulus sp.2 & 0 & 0 & 22 & 0 & 0 & 0 & 0 & 0 & 0 & 0 & 0 & 0 \\
\hline & & Cirratulus sp. 3 & 17 & 22 & 156 & 0 & 0 & 0 & 0 & 25 & 125 & 0 & 0 & 0 \\
\hline & & Caulleriella sp. & 0 & 0 & 0 & 0 & 0 & 0 & 0 & 0 & 0 & 50 & 0 & 0 \\
\hline & & Tharyx sp. & 1802 & 2289 & 1311 & 141 & 1111 & 955 & 0 & 0 & 0 & 25 & 0 & 0 \\
\hline & Cossuridae & & & & & & & & & & & & & \\
\hline & & Cossura sp. & 0 & 0 & 0 & 44 & 0 & 0 & 0 & 25 & 75 & 0 & 0 & 0 \\
\hline & Dorvilleidae & & & & & & & & & & & & & \\
\hline & & Dorvillidae sp. & 7 & 44 & 22 & 0 & 0 & 0 & 0 & 0 & 0 & 0 & 0 & 0 \\
\hline & & Ophryotrocha sp. & 0 & 0 & 0 & 0 & 0 & 0 & 25 & 0 & 0 & 0 & 0 & 0 \\
\hline & Polynoidae & & & & & & & & & & & & & \\
\hline & & Euphione sp. & 0 & 0 & 0 & 0 & 0 & 0 & 0 & 0 & 0 & 0 & 75 & 0 \\
\hline & & Eunoe sp. & 0 & 0 & 0 & 0 & 0 & 0 & 0 & 0 & 0 & 0 & 50 & 0 \\
\hline & Eunicidae & & & & & & & & & & & & & \\
\hline & & Eunice sp. & 2 & 111 & 0 & 0 & 0 & 0 & 0 & 0 & 0 & 25 & 0 & 0 \\
\hline & Glyceridae & & & & & & & & & & & & & \\
\hline & & Glycera alba & 15 & 89 & 44 & 0 & 0 & 0 & 75 & 0 & 50 & 275 & 175 & 75 \\
\hline & Goniadidae & & & & & & & & & & & & & \\
\hline & & Glycinde sp. & 131 & 0 & 0 & 0 & 0 & 22 & 0 & 0 & 0 & 50 & 0 & 0 \\
\hline & Goniadidae & & & & & & & & & & & & & \\
\hline & & Goniada sp. & 0 & 0 & 0 & 0 & 0 & 0 & 0 & 0 & 0 & 0 & 0 & 50 \\
\hline & Hesionidae & & & & & & & & & & & & & \\
\hline & & Ophiodromus sp. & 0 & 0 & 0 & 0 & 0 & 0 & 0 & 0 & 0 & 0 & 0 & 25 \\
\hline & & Hesionidae sp. & 0 & 0 & 22 & 0 & 0 & 0 & 0 & 0 & 0 & 0 & 0 & 0 \\
\hline & Amphinomidae & & & & & & & & & & & & & \\
\hline & & Pseudeurythoe sp. & 15 & 133 & 89 & 89 & 0 & 0 & 0 & 0 & 0 & 0 & 0 & 0 \\
\hline & & Harmothos sp. & 0 & 0 & 0 & 0 & 0 & 0 & 0 & 0 & 0 & 0 & 25 & 0 \\
\hline & Sabellidae & & & & & & & & & & & & & \\
\hline & & Euchone sp. & 0 & 0 & 0 & 0 & 0 & 0 & 0 & 0 & 0 & 0 & 75 & 0 \\
\hline & & Sabellidae & 0 & 0 & 0 & 0 & 0 & 44 & 0 & 0 & 0 & 0 & 0 & 0 \\
\hline & & Chone sp. & 0 & 0 & 0 & 0 & 0 & 0 & 0 & 0 & 0 & 0 & 0 & 0 \\
\hline & & Hydroides sp. & 0 & 0 & 0 & 0 & 0 & 0 & 0 & 25 & 0 & 0 & 0 & 0 \\
\hline & & Megalomma sp. & 0 & 0 & 0 & 0 & 0 & 0 & 0 & 0 & 0 & 705 & 0 & 0 \\
\hline & & Jasmineira sp. & 7 & 89 & 0 & 0 & 89 & 22 & 0 & 25 & 0 & 0 & 0 & 25 \\
\hline & Paraonidae & & & & & & & & & & & & & \\
\hline & & Aricidae sp. & 3 & 111 & 22 & 9 & 89 & 22 & 0 & 25 & 0 & 0 & 0 & 0 \\
\hline & & Levinsenia sp. & 7 & 333 & 178 & 22 & 0 & 44 & 0 & 0 & 0 & 0 & 0 & 0 \\
\hline & Lumbrinereidae & & & & & & & & & & & & & \\
\hline & & Lumbrineris longifolia & 30 & 44 & 111 & 89 & 178 & 44 & 0 & 125 & 0 & 0 & 25 & 25 \\
\hline
\end{tabular}


Citation: Baban SI, Periasamy R, Kalyan D (2016) Macrobenthic Community Structure Response to Coastal Hypoxia off Southeastern Arabian Sea. J Coast Zone Manag 19: 436. doi:10.4172/2473-3350.1000436

Page 8 of 10

\begin{tabular}{|c|c|c|c|c|c|c|c|c|c|c|c|c|c|c|}
\hline & & Ninoe nigripes & 0 & 0 & 0 & 0 & 0 & 0 & 0 & 50 & 0 & 0 & 75 & 0 \\
\hline & Ampharetidae & & & & & & & & & & & & & \\
\hline & & Melinna sp. & 0 & 0 & 0 & 0 & 0 & 0 & 0 & 25 & 0 & 0 & 0 & 0 \\
\hline & & Amage sp. & 12 & 89 & 0 & 17 & 0 & 111 & 0 & 25 & 0 & 0 & 0 & 0 \\
\hline & Magelonidae & & & & & & & & & & & & & \\
\hline & & Magelona cincta & 10 & 44 & 0 & 0 & 0 & 133 & 75 & 175 & 0 & 100 & 0 & 25 \\
\hline & Nephtyidae & & & & & & & & & & & & & \\
\hline & & Nepthys inermis & 0 & 89 & 0 & 0 & 0 & 0 & 0 & 0 & 0 & 0 & 0 & 0 \\
\hline & & Nepthys sp. & 0 & 22 & 0 & 267 & 133 & 0 & 0 & 0 & 0 & 0 & 0 & 0 \\
\hline & Nereididae & & & & & & & & & & & & & \\
\hline & & Micronereides sp. & 0 & 89 & 0 & 0 & 0 & 0 & 0 & 0 & 0 & 0 & 0 & 0 \\
\hline & & Neries sp. & 0 & 0 & 0 & 0 & 0 & 0 & 150 & 0 & 0 & 0 & 0 & 0 \\
\hline & Onuphide & & & & & & & & & & & & & \\
\hline & & Onuphis sp. & 79 & 0 & 22 & 22 & 0 & 0 & 0 & 25 & 0 & 0 & 0 & 0 \\
\hline & Pisionidae & & & & & & & & & & & & & \\
\hline & & Pisionidens sp. & 0 & 0 & 0 & 0 & 0 & 0 & 0 & 0 & 0 & 0 & 50 & 0 \\
\hline & Phyllodocidae & & & & & & & & & & & & & \\
\hline & & Eteone sp. & 0 & 0 & 0 & 0 & 0 & 0 & 0 & 25 & 0 & 25 & 50 & 0 \\
\hline & & Phyllodoce sp. & 40 & 44 & 0 & 2 & 0 & 22 & 0 & 0 & 0 & 75 & 75 & 0 \\
\hline & Spionidae & & & & & & & & & & & & & \\
\hline & & Prionospia steenstrupi & 0 & 0 & 0 & 0 & 0 & 0 & 150 & 350 & 0 & 0 & 0 & 200 \\
\hline & & Prionospia cirrifera & 706 & 44 & 178 & 178 & 0 & 89 & 275 & 25 & 200 & 950 & 1350 & 25 \\
\hline & & Prionospia pygmaea & 10 & 0 & 22 & 22 & 0 & 22 & 125 & 25 & 75 & 600 & 350 & 125 \\
\hline & & Paraprionospia cordifolia & 5 & 67 & 22 & 22 & 89 & 22 & 250 & 1375 & 50 & 1550 & 1200 & 325 \\
\hline & & Prionospia cirrobranchiata & 2 & 0 & 0 & 22 & 0 & 0 & 0 & 450 & 50 & 0 & 0 & 0 \\
\hline & & Prionospio sp. & 168 & 178 & 311 & 311 & 44 & 22 & 0 & 0 & 0 & 0 & 0 & 0 \\
\hline & & Prionospio aucklandica & 0 & 44 & 22 & 22 & 44 & 133 & 0 & 0 & 0 & 0 & 0 & 0 \\
\hline & & Scolelepis sp. & 0 & 0 & 0 & 0 & 0 & 0 & 0 & 0 & 0 & 0 & 200 & 0 \\
\hline & & Spiophanes sp. & 0 & 0 & 0 & 0 & 0 & 0 & 0 & 0 & 0 & 1000 & 0 & 0 \\
\hline & & Streblospio sp. & 0 & 0 & 0 & 0 & 0 & 0 & 175 & 0 & 0 & 125 & 0 & 0 \\
\hline & Orbiniidae & & & & & & & & & & & & & \\
\hline & & Scoloplos sp. & 0 & 22 & 0 & 0 & 0 & 0 & 0 & 0 & 0 & 900 & 50 & 0 \\
\hline & Syllidae & & & & & & & & & & & & & \\
\hline & & Syllids sp. & 12 & 0 & 0 & 0 & 0 & 0 & 0 & 0 & 0 & 0 & 0 & 0 \\
\hline & & Exogone sp. & 15 & 200 & 22 & 0 & 0 & 0 & 0 & 0 & 0 & 0 & 0 & 0 \\
\hline & Trichobranchidae & & & & & & & & & & & & & \\
\hline & & Trichobranchus sp. & 0 & 0 & 0 & 0 & 0 & 0 & 0 & 25 & 0 & 0 & 0 & 0 \\
\hline & Terebellidae & & & & & & & & & & & & & \\
\hline & & Terebellides sp. & 5 & 22 & 0 & 0 & 0 & 0 & 0 & 75 & 0 & 0 & 25 & 0 \\
\hline & & Lanice conchilega & 0 & 0 & 0 & 0 & 0 & 0 & 0 & 50 & 0 & 0 & 50 & 0 \\
\hline & & Amphitrite sp. & 0 & 0 & 0 & 0 & 0 & 0 & 0 & 0 & 0 & 25 & 0 & 0 \\
\hline Crustacea & & & & & & & & & & & & & & \\
\hline & & Isopoda & 0 & 0 & 0 & 0 & 0 & 0 & 0 & 0 & 0 & 75 & 50 & 0 \\
\hline & & Mystidea & 0 & 0 & 0 & 0 & 0 & 0 & 0 & 0 & 0 & 0 & 50 & 0 \\
\hline & & Ostropoda & 0 & 22 & 0 & 0 & 0 & 0 & 0 & 25 & 0 & 0 & 0 & 50 \\
\hline & & Shrimp larva & 32 & 22 & 0 & 0 & 0 & 0 & 0 & 0 & 25 & 0 & 75 & 0 \\
\hline & & Sand dollar & 0 & 0 & 0 & 0 & 0 & 0 & 0 & 0 & 0 & 0 & 225 & 0 \\
\hline & & Tanaidacea & 15 & 89 & 0 & 0 & 0 & 22 & 0 & 25 & 0 & 0 & 0 & 0 \\
\hline & & Decapoda larva & 0 & 0 & 0 & 0 & 0 & 0 & 0 & 0 & 0 & 0 & 0 & 25 \\
\hline & & Cumacea & 7 & 22 & 22 & 0 & 89 & 0 & 0 & 50 & 0 & 50 & 0 & 0 \\
\hline & & Caperlloidea & 12 & 0 & 0 & 0 & 0 & 22 & 50 & 50 & 0 & 775 & 50 & 0 \\
\hline & & Ampelisca sp. & & 0 & 0 & 0 & 0 & & 25 & 50 & 0 & 350 & 50 & 0 \\
\hline & & Byblis sp. & 0 & 0 & 0 & 0 & 0 & 0 & 0 & 0 & 0 & 150 & 0 & 0 \\
\hline & & Lijeborgiidae & 0 & 0 & 0 & 0 & 0 & 0 & 25 & 25 & 0 & 50 & 0 & 0 \\
\hline Bivalvia & & & & & & & & & & & & & & \\
\hline & & Bivalvia & 99 & 0 & 178 & 0 & 0 & 0 & 75 & 75 & 0 & 100 & 50 & 0 \\
\hline & & Gnathia cerina & 0 & 0 & 22 & 0 & 0 & 0 & 0 & 0 & 0 & 0 & 0 & 0 \\
\hline & & Arca sp. & 0 & 0 & 0 & 0 & 0 & 22 & 0 & 0 & 0 & 0 & 0 & 0 \\
\hline & & Babylonia & 0 & 22 & 0 & 0 & 0 & 0 & 0 & 0 & 0 & 0 & 0 & 0 \\
\hline & & Corbiculidae & 0 & 0 & 0 & 0 & 0 & 0 & 0 & 0 & 0 & 0 & 0 & 0 \\
\hline
\end{tabular}


Citation: Baban SI, Periasamy R, Kalyan D (2016) Macrobenthic Community Structure Response to Coastal Hypoxia off Southeastern Arabian Sea. J Coast Zone Manag 19: 436. doi:10.4172/2473-3350.1000436

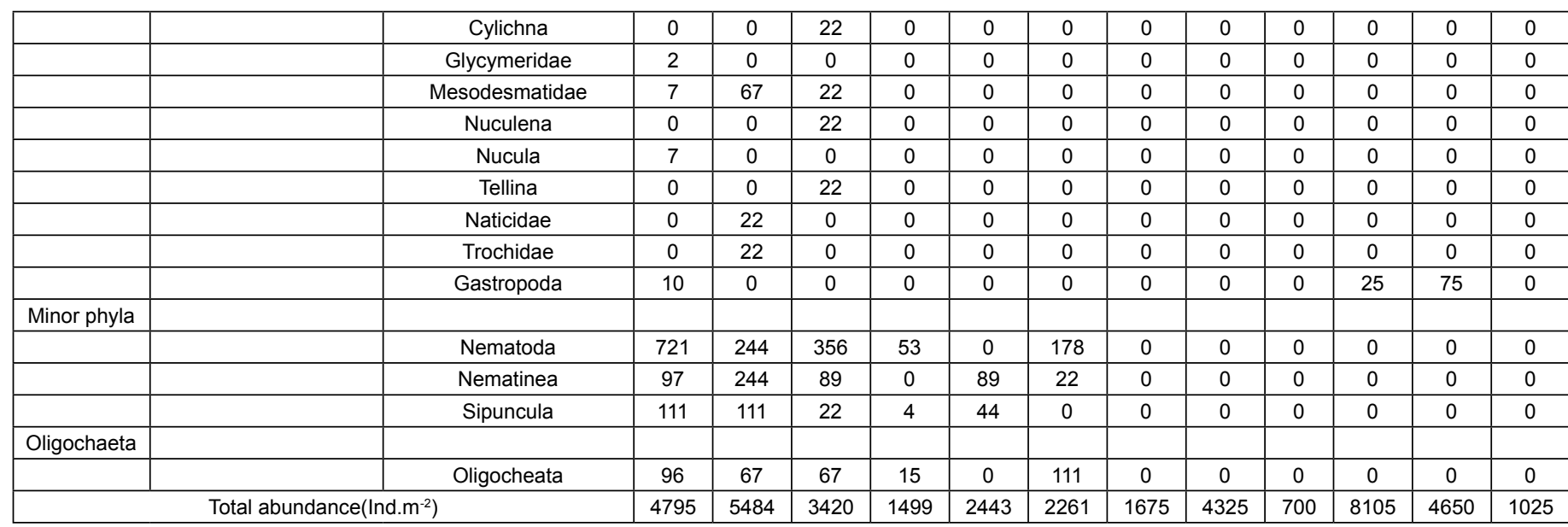

Table 6: Mean abundances of macrofauna (ind. $\mathrm{m}^{2}$ ) at normoxia (SIM) and hypoxia (SM) conditions.

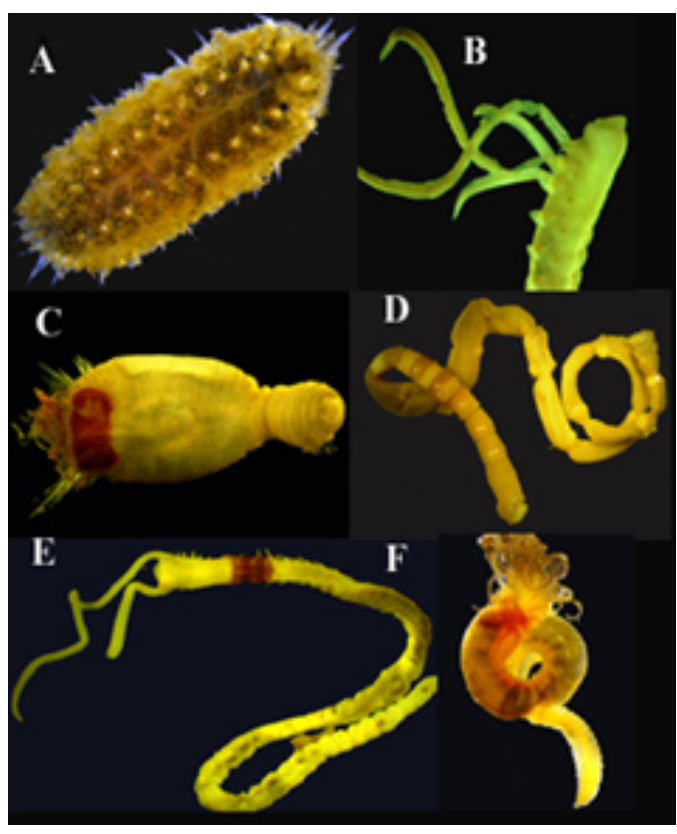

Figure 8: A: Thormora jukesii, B: Paraprionospio cordifolia, C: sternaspis scutata, D: Maldanella sp. E: Magelona cincta F. Terebellides stroemi. In figure $B, E$ and $F$ respiratory surface gills improved in hypoxia condition, photograph of anterior part of polychaetes with well-developed branchia.

species with an expanded branchial structure appeared due to the adaptations at low oxygen conditions. It also suggested that branchial are importance for feeding rather than for gas exchange.

\section{Conclusions}

The present study reveals that macrofaunal community structure changes by natural occurrence of coastal hypoxia in the SEAS and event of hypoxia repeatedly in the SM. The species diversity showed the seasonal variation and the $P$. cordifolia tolerated and respond to hypoxic condition and heavy recruitment that could be tolerated a wide range of low oxygen conditions. Most recruited macrofauna in fall were composed of opportunistic species and they disappeared again with the next normoxia condition. Further, we observed that Tharyx sp. and $P$. cordifolia could be second order opportunistic species in surface deposit-feeder. The DO and environmental variables may influence the changes in macrofauna community structural with alteration of food webs. The surface deposit feeder and hypoxic tolerant species were highly dominant when compared to suspension feeder and hypoxic intolerant species.

\section{Acknowledgements}

The authors are grateful to Director, CSIR-National Institute of Oceanography, for his encouragement and permission to publish this work. We also express our gratitude to Ministry of Earth Science, India for their financial support and for providing CVR Sagar Sukti and FORV Sagar Sampada for sample collection and onboard analysis. The entire team of SIP project for all the help rendered during the field study. Financial support for Mr. Kalyan De and Mr. Perisamy R received from the MOES under the COMAPS project (GAP-2740).

\section{References}

1. Lenihan HS, Micheli F (2001) Soft sediment communities. Marine Community Ecology. Sinauer Associates, Sunderland, MA. pp: 253-287.

2. Feder HM, Jewett SC (1981) Feeding interactions in the eastern Bering Sea with emphasis on the benthos. The Eastern Bering Sea Shelf Oceanography and Resources: Office of Marine Pollution Assessment and National Oceanic and Atmospheric Administration. University of Washington Press, Seattle 2: 1229-1261.

3. Rhoads DC (1974) Organism-sediment relations on the muddy sea floor Oceanogr Mar Biol Annu Rev 12: 263-300.

4. Aller RC, Yingst JY (1985) Effects of the marine deposit feeders Heteromastus filiformis (Polychaeta), Macoma balthica (Bivalvia), and Tellina texana (Bivalvia) on averaged sedimentary solute transport, reaction rates, and microbial distributions. Journal of Marine Research 43: 615-645.

5. Bylyard GR (1987) The value of benthic infauna in marine pollution monitoring studies. Marine Pollution Bulletin 18: 581-585.

6. Warwick RM (1993) Environmental impact studies on marine communities: pragmatical considerations. Australian Journal of Ecology 18: 63-80.

7. Levin LA, Ekay W, Gooday AJ, Jorissen F, Middelburg JJ, et al. (2009) Effect of natural and human- induced hypoxia on coastal benthos. Biogeosciences 6: 2063-2098.

8. Kemp WM, Testa JM, Conley DJ, Gilbert D, Hagy JD (2009) Temporal responses of coastal hypoxia to nutrient loading and physical controls. Biogeosciences 6 : 2985-3008.

9. Tyson RV, Pearson TH (1991) Modern and ancient continental shelf anoxia: an overview. Geological Society Special Publication 55: 1-24.

10. Naqvi SWA, Narvekar PV, Desa E (2006) Coastal biogeochemical processes in the north Indian Ocean (14, SW). In: Robinson AR, Brink KH (Eds). The Sea: Ideas and observations on progress in the study of the seas. Interdisciplinary regional studies and syntheses. Harvard University Press; Cambridge, USA pp: 723-781. 
Citation: Baban SI, Periasamy R, Kalyan D (2016) Macrobenthic Community Structure Response to Coastal Hypoxia off Southeastern Arabian Sea. J Coast Zone Manag 19: 436. doi:10.4172/2473-3350.1000436

Page 10 of 10

11. Levin LA (2003) Oxygen minimum zone benthos: adaptation and community response to hypoxia. Oceanogr Mar Biol Annu Rev 41: 1-45.

12. Ingole BS, Sautya S, Sivadas SK, Singh R, Nanajkar M (2010) Macrofaunal community structure in the western Indian continental margin including the oxygen minimum zone. Mar Ecol 31: 148-166.

13. Madhupratap M, Kumar S, Bhattathri PMA, Kumar M, Raghukumar S, et al. (1996) Mechanism of the biological response to winter cooling in the northeastern Arabian Sea. Nature 384: 549-552.

14. Maheswaran M (2000) Upwelling along the southwest coast of India. Indian J Mar Sci 15: 20-24.

15. Krishna K (2008) Coastal upwelling along the southwest coast of India - ENSO modulation. Ocean Science Discussion 5: 123-134.

16. Rao AD, Madhu J, Indu J, Mahapatra DK, Babu SV (2004) Modeling of coastal upwelling along the southwest coast of India using POM. Proc METOC. pp: 183-188.

17. Wu SSR (2002) Hypoxia: from molecular responses to ecosystem responses. Marine Poll Bull 45: 35-45.

18. McNeil DG, Closs GP (2007) Behavioural responses of a southeast Australian floodplain fish community to gradual hypoxia. Freshwater Biology 52: 412-420.

19. Gray JS, Wu RSS, Or YY (2002) Effects of hypoxia and organic enrichment on the coastal marine environment. Mar Ecol Prog Ser 238: 249-279.

20. Solan M, Cardinale BJ, Downing AL, Engelhardt KAM, Ruesink JL, et al. (2004) Extinction and ecosystem function in the marine benthos. Science 306: 11771180.

21. Taylor JC, Miller JM (2001) Physiological performance of juvenile southern flounder, Paralichthys lethostigma, in chronic and episodic hypoxia. J Exp Mar Biol Ecol 258: 195-214

22. Conley DJ, Carstensen J, Vaquer SR, Duarte CM (2009) Ecosystem thresholds with hypoxia. Hydrobiologia 629: 21-29.

23. Rabalais NN, Diaz RJ, Levin LA, Turner RE, Gilbert D, et al. (2010) Dynamic and distribution of natural and human-cause hypoxia. Biogeosciences 7: 585619

24. Long WC, Seitz RD (2009) Hypoxia in chesapeake bay tributaries: Worsening effects on macrobenthic community structure in the York river. Estuaries and Coasts 32: 287-297.

25. Gooday AJ, Jorissen F, Levin LA, Middelburg JJ, Naqvi SWA, et al. (2009) Historical records of coastal eutrophication-induced hypoxia. Biogeosciences 6: 1707-1745.

26. Ingole BS, Sivadas SK, Nanajkar M, Sautya S, Singh R, et al. (2009) A comparative study of macrobenthic community from harbours along the central west coast of India. Environ Monit Assess 154: 135-146.

27. Strickland JDH, Parsons TR (1968) A practical handbook of sea water analysis Canada Bulletin. p. 311.

28. Day JH (1967) A monograph on the polychaeta of Southern Africa, Part (Errantia) and Part II (Sedentaria). Trustees of the British Museum, Natural History, London. pp: 1-878.

29. Fauchald K (1977) The polychaete worms, definitions and keys to the orders, families and genera. Natural History Museum of Los Angeles County Science Series 28: 1-190.
30. Margalef R (1968) Perspectives in ecological theory. University of Chicago Press, Chicago. p. 111.

31. Pielou EC (1969) An introduction to mathematical ecology. Wiley and Sons, New York.

32. Shannon CE, Wiener W (1949) The mathematical theory of communication University of Illinois Press, Urbana. p. 177.

33. Clarke KR, Warwick RM (1994) Change in marine communities. Plymouth Marine Laboratory.

34. Fauchald K, Jumars PA (1979) The diet of worms: a study of polychaete feeding guilds. Oceanography and Marine Biology: Annual Review 17: 193-284.

35. Dries RR, Theed H (1974) Saverst off mangel resistant Mariner Bodenvertebraten aus der Westlichen Ostsee. Marine Biology 25: 327-333.

36. Srinivas K, Kumar PK (2006) Atmospheric forcing on the seasonal variability of sea level at Cochin, southwest coast of India. Continental Shelf Research 26: 1113-123.

37. Pearson $\mathrm{TH}$, Rosenberg $\mathrm{R}$ (1978) Macrobenthic succession in relation to organic enrichment and pollution of the marine environment. Oceanogr Mar Biol Annu Rev 19: 229-311.

38. Jayaraj KA, Jayalakshmi KV, Saraladevi K (2007) Influence of environmenta properties on macrobenthos in the northwest Indian shelf. Environ Monit Assess 127: 459-475.

39. Agrawal AA, Klein CN (2000) What omnivores eat: direct effects of induced plant resistance on herbivores and indirect consequences for diet selection by omnivores. J Anim Ecol 69: 525-535.

40. Varshney PK, Govindan K, Gaikwad UD, Desai BN (1988) Macrobenthos off Versova (Bombay), West Coast of India, in relation to environmental conditions. Indian J Mar Sci 17: 222-227.

41. Joydas TV, Damodaran R (2009) Infaunal macrobenthos along the shelf waters of the west coast of India, Arabian Sea. Indian J Mar Sci 38: 191-204.

42. Gallardo VA, Palma M, Carrasco FD, Gutierrez D, Levin LA, et al. (2004) Macrobenthic zonation caused by the oxygen minimum zone on the shelf and slope off central Chile. Deep-Sea Research II 51: 2475-2490.

43. Palma M, Quiroga E, Gallardo VA, Arntz W, Gerdes D, et al. (2005) Macrobenthic animal assemblages of the continental margin off Chile. J Mar Biol Assoc UK 85: 233-245.

44. Diaz RJ, Rosenberg R (1995) Marine benthic hypoxia: a review of its ecological effects and the behavioral responses of benthic macrofauna. Annual Review Oceanography Marine Biology 33: 245-303.

45. Borja A, Franco J, Perez V (2008) A marine biotic index to establish the ecological quality of soft-bottom benthos within European estuarine and coastal environments. Marine Poll Bull 12: 1100-1114.

46. Lamont PA, Gage JD (2000) Morphological responses of macrobenthic polychaetes to low oxygen on the Oman continental slope, NW Arabian Sea. Deep-Sea Research 47: 9-24. 